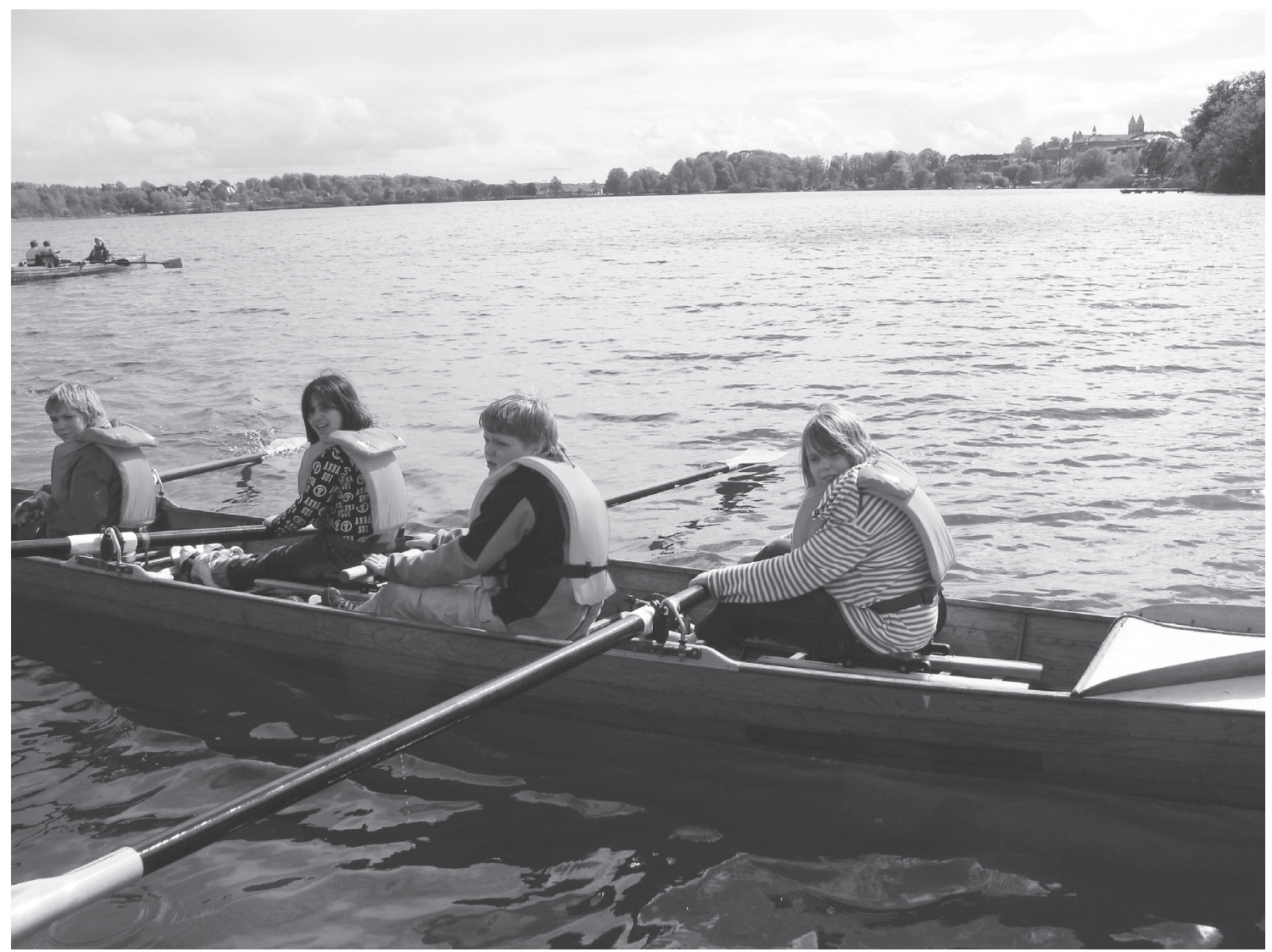

I 2006 udmøntedes et satspuljeforlig i en allokering af 40 mio. kr. til »Idrætsprojekter for vanskeligt stillede børn«. Puljen blev udbudt af Kulturministeriet. En del af pengene var øremærket til overvægtige, vanskeligt stillede børn og til en evaluering af indsatsen. 34 projekter for overvægtige børn og unge blev støttet. Billedet er fra et projekt i Viborg. (Fotograf: Lone Simonsen)

\title{
En verden til forskel \\ Stat og civilsamfundets indsats omkring idræt for vanskeligt stillede, overvæegtige børn
}




\section{INDLEDNING}

I Danmark bliver idrætsforeninger i disse år i stigende grad inddraget i forsøg på at løse velfærdspolitiske problemer. Projekter målrettet udsatte eller vanskeligt stillede grupper udbydes til den frivillige idræt, hvis organisering repræsenterer velfærdsstatslige mulighedsbetingelser (Hegland, 2001). Artiklen, der tager udgangspunkt i en evaluering af idrætsprojekter for overvægtige børn (Michelsen la Cour, 2009), viser, at de projektmetoder, der bruges til rekruttering af særlige målgrupper samt disses fastholdelse, endnu er på det eksperimentelle stadie.

I 2006 udmøntedes et satspuljeforlig i en allokering af 40 mio. kr. til »Idrætsprojekter for vanskeligt stillede børn«. Puljen blev udbudt af Kulturministeriet. En del af pengene var øremærket til overvægtige, vanskeligt stillede børn, til evaluering af indsatsen og et dertil knyttet ph.d.-studie.

Puljer kan betragtes som et mulighedsrum for udvikling eller afprøvning af velfærdspolitiske metoder. Denne pulje til udvikling af projekter for vanskeligt stillede børn skal ikke bare lette adgangen til den organiserede idræt, men også bidrage til at fastholde denne gruppe. Dermed kan puljen betragtes som en forsøgsramme for løsning af nye sociale og sundhedsmæssige problemer. Case-materialet er numerisk lille, men principielt eksemplarisk for, hvordan foreninger KAN gribe til løsning af problemer med adgang til og fastholdelse af idrætsuvante, vanskeligt stillede grupper. Case-udvalget er repræsentativt for den sociologiske afhandlings større casemateriale, nemlig de 23 projekter i ph.d.-afhandlingens case-materiale.

Med udgangspunkt i tre udvalgte cases undersøges, hvilke strategier foreninger anvender $\mathrm{i}$ løsningen af velfærdspolitiske opgaver. Vel- færdspolitiske opgaver skal i denne sammenhæn forstås som de opgaver, staten udbyder til det frivillige foreningsliv $i$ et forsøg på at få velfærdsproblemer løst på en anden måde, end det sker inden for det professionelle sundhedsvæsen eller det professionelle sociale arbejde. Selvom foreningernes frivillige ikke har formelle velfærdspolitiske kompetencer, betragtes de af staten som velfærdspolitiske mulighedsbetingelser $\mathrm{i}$ det omfang, de går ind i opgaveløsningen.

Opgavernes mål er imidlertid ikke entydige, idet der foregår en sammenblanding af sundhedspolitiske og socialpolitiske målsætninger. Projekterne i puljen for de overvægtige børn skal således ikke skabe et vægttab for børnene, men primært fokusere på at få børnene fastholdt $\mathrm{i}$ foreningerne. Det bliver dermed interessant både fra et velfærdspolitisk og et foreningspolitisk perspektiv at undersøge, hvordan målene omsættes til metoder $\mathrm{i}$ foreningerne, og hvilke konsekvenser puljepolitikken har for de foreninger, der går ind i dette arbejde.

Evalueringsrapporten Virker det? Og i givet fald hvorfor? (Michelsen la Cour, 2009) ${ }^{1}$ peger på (mindst) tre centrale udfordringer i projekter målrettet vanskeligt stillede eller udsatte grupper:

1. Den ene udfordring er rekrutteringen af målgrupper, der ikke dyrker idræt.

2. Den anden udfordring er fastholdelse af disse grupper, der oftest ikke har den opbakning hjemmefra, som fastholdelse i den organiserede idræt afhænger af, ligesom målgruppen kan have vanskelige sociale problemstillinger med sig.

3. Den tredje udfordring er samarbejdet med velfærdsprofessionelle omkring særlige sociale problemstillinger $\mathrm{i}$ arbejdet med de vanskeligt stillede grupper. Velfærdsprofessi- 
onelle er i evalueringsrapporten pædagoger, skolelærere og sundhedsplejersker, der er offentligt ansat og tilknyttet enten de institutioner eller kommuner, hvor foreningerne er hjemmehørende.

Evalueringen er anlagt som en kvalitativ evaluering af 23 idrætsprojekter for overvægtige og svært overvægtige børn. Idrætsprojekternes kortsigtede mål har været at sikre disse målgruppers rekruttering til og deltagelse i organiseret idræt i særligt tilrettelagte projekter over hele landet. Det langsigtede mål er at sikre børnenes og de unges permanente deltagelse i den organiserede idræt, ikke vægttab. Projekternes udformning er forankret i forestillinger om, at overvægt og vanskeligt stillethed hos børn og unge både skyldes en kombination af barrierer $\mathrm{i}$ forhold til den organiserede idræts organisering, udsatte børn og unges manglende ressourcer $\mathrm{i}$ forhold til at kunne deltage i jævnaldrendes netværker og vanskeligt stillede familiers viden i forhold til sund kost og fysisk aktivitet.

\section{VIL IDRATSFORENINGERNE PÅTAGE SIG VELFARDSPOLITISIKE OPGAVER?}

Ikke alle foreninger vil eller kan arbejde ud fra en social orientering (Ibsen, 2006). Ifølge en undersøgelse drejer det sig om ca. $10 \%$ af alle idrætsforeninger, der ønsker at gøre det (Ibsen, 2006). Det kan ud fra et foreningspolitisk perspektiv indvendes, at idrætsforeningernes opgave slet ikke er at tage sig af børn og unge, hvis svage tilknytning til fysisk aktivitet, manglende fysiske kompetencer og manglende forældreopbakning ligger langt fra idrætsforeningernes opgave. Men at foreningerne er sat $i$ verden for at skabe optimale rammer omkring elite- og breddeidrætsaktiviteter - og at den lille ${ }^{2}$, vanskeligt, stillede gruppe, hvori indgår overvægtige og

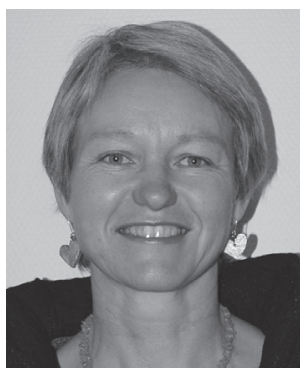

svært overvægtige børn og unge, i stedet kunne tilbydes motion i en ramme, der bedre kan målrettes en systematisk og professionel sundhedsindsats.

I en nyere evaluering af det danske foreningslivs potentiale $\mathrm{i}$ forhold til at udbyde særlige tilbud, rekruttere samt fastholde vanskeligt stillede målgrupper udtaler en projektejer:

"I må ikke tro, at de frivillige foreningsledere, de klarer denne her opgave, den er for kompleks. Det er et stykke socialt arbejde og det er ikke en foreningsopgave. I værste fald tabes de mennesker, der har det værst.« (Orla Østerby, Tangsøe Forenede Sportsklubber i Michelsen la Cour, 2009, s. 63).

En anden projektejer er afvisende over for idéen om, at idrætsforeninger forudsætningsløst kan gøre en forskel:

"Hvis det 'bare' er en almindelig forening, hvor man ikke har nogen uddannelsesbaggrund - andet end at man er kontordame eller har et almindeligt arbejde og er i en almindelig forening - så har man slet ikke de kompetencer, der skal til for at kunne varetage det socialpædagogiske arbejde. Det har man slet ikke mulighed for. Så det er fuldstændig misforstået, at det er en opgave 
som idrætsforeningerne skal tage sig af.« (Annette Winther, Herlev IF i Michelsen la Cour, 2009, s. 60).

Evalueringen viser, at andre idrætsprojektejere ser mindre dystert på løsningen af sociale opgaver inden for rammerne af en idrætsforening, selvom opgaven byder på langt flere udfordringer end det blot at få en fysisk aktivitet til at fungere for overvægtige børn (Michelsen la Cour, 2010, s. 61). Der er altså tale om holdningsforskelle mellem foreningernes frivillige, ligesom frivillige $\mathrm{i}$ foreningerne bliver ved med at søge de puljer, staten udbyder.

Det er interessant fra et velfærdspolitisk perspektiv at undersøge, hvilke metoder og hvilke projekter, der bedst opfylder ministeriets målsætning. Både evalueringen og den efterfølgende sociologiske analyse viser, at foreninger har forskellige ressourcer, og at projektejere har forskellige perspektiver på opgaveløsningen såvel som forskellige kompetencer $\mathrm{i}$ forhold til at gå ind i det velfærdspolitiske felt. Metodeanvendelsen i projektløsningen er tilsvarende varieret.

Det er artiklens hensigt at vise, hvordan de strategier, foreninger anvender i løsningen af velfærdspolitiske opgaver, kan betragtes som modeller for et velfærdspolitisk samarbejde, der udvider foreningernes nære idrætsorienterede målsætning. Strategierne omsættes til metoder i foreningerne, og en af konklusionerne er, at foreningerne i case-materialet som konsekvens af puljepolitikken udvikler sig organisatorisk, styrker forbindelsen med lokalsamfundets netværker og øger forbruget af social kapital samt styrker samfundets sammenhængskraft. I et velfærdspolitisk perspektiv skaber et øget forbrug af social kapital øget social værdi og dermed øget velfærd.
Artiklens case-materiale stammer fra evalueringen af den del af idrætsprojekterne for de vanskeligt stillede børn, der blev udbudt som et ph.d.-studie. Evalueringen gennemførtes for Kulturministeriet i perioden 2006-2009. Den efterfølgende sociologiske analyse af materialet er at finde i ph.d.-afhandlingen Idratsforeningers velfardspotentiale: En sociologisk analyse af sammenhoengen mellem velfaerdspolitik, social kapital og socialt entreprenørskab i 21 idrcetsprojekter for vanskeligt stillede børn. Afhandlingen blev forsvaret i marts 2011.

\section{BAGGRUND OMKRING PULJEMIDLERNE OG DE UDVALGTE CASES}

Idrætsprojekter for vanskeligt stillede, overvægtige børn og unge blev udbudt i 2006 inden for rammerne af den organiserede frivillige idræt. 34 projekter for overvægtige børn og unge blev støttet, og evalueringen af disse projekter udbød daværende kulturminister Brian Mikkelsen som et ph.d.-studie. De 34 projekter modtog støtte på mellem $10.000 \mathrm{kr}$. og 1.200 .000 kr. i en periode på mellem et og tre år mellem september 2006 og juni 2009. Puljen støttede desuden projekter for anbragte, etniske, mindrebemidlede og handicappede børn og unge for en samlet sum af $40 \mathrm{mio}$. $\mathrm{kr}$.

De tre projekter, der er udvalgt som cases i artiklen, har nogle væsentlige fællestræk: De har en treårig løbetid og en forankring i jyske landsbyidrætsforeninger inden for et område, der strækker sig geografisk fra landsbyen Bækmarksbro i Vestjylland over Durup i Nordsalling for at ende i Hvilsom i Vesthimmerland. Foreningerne er beliggende i områder, der er relativt sammenlignelige socio-økonomisk og infrastrukturelt. Såvel Vestjylland som Salling og Himmerland er områder, der er præget af fraflytning, lav befolkningstæthed, få arbejdsplad- 
ser, arbejdsløshed, landsbyskolelukninger, lav uddannelseskapital, begrænset økonomi, begrænset offentlig transport, få fritidstilbud for børn og unge og få foreninger. Transport udgør en barriere for foreningsdeltagelse i disse områder. Blandt befolkningerne $\mathrm{i}$ disse områder er der stigende overvægt og få sundhedstilbud.

Alle tre projekter er udformet og søgt af stærkt engagerede projektejere, der i foreningsengagementet forener et stærkt socialt og lokalt engagement. Alle tre projekter kan betragtes som relativt succesfulde: Tangsøe Forenede Sportsklubber har fastholdt 25 børn og unge (25\% af deltagerne), Nordsalling Bokseklub har fastholdt 17 børn og unge (40\% af deltagerne), og IF KVIK, Vesthimmerland har fastholdt 20 børn (100\% af deltagerne). Projekterne har 5-9-årige, 10-13-årige og 14-17-årige som målgruppe. De er støttet med henholdsvis 1.005.000 kr., 90.000kr. og 114.300 kr. I Tangsøeprojektet er prisen pr. fastholdt barn således $40.000 \mathrm{kr}$., i Nordsalling er prisen pr. fastholdt barn $6.000 \mathrm{kr}$. pr. barn, og i Vesthimmerland er prisen pr. barn $5.700 \mathrm{kr}$. (cirkatal).

Projekternes opgaveforståelser afspejler foreningernes identifikationer af de barrierer, der er for målgruppens foreningsdeltagelse.

\section{CASE TANGSØE FORENEDE SPORTSKLUBBER}

Den første case, herefter kaldet case Tangsøe, er et projekt for alle puljens aldersgrupper, men i praksis er deltagerne mellem 8 år og 14 år. Projektdeltagerne er rekrutteret gennem den lokale sundhedsplejerske og gennem avisannoncer, og da oplandet er stort, kommer en del af deltagerne langvejs fra. Foreningen har lokaler i landsbyen Bækmarksbro.

Puljens opdeling i aldersdifferentierede grupper med forskellige aktiviteter eksisterer ikke på dette projekt. Efter seks måneder slutter de- res projekt, og nye deltagere starter. Samlet set har 67 børn deltaget på hold af seks måneders varighed. Projektets opgaveforståelse, hvori projektets mål betragtes som øget sundhed i form af vægttab, øgede bevægekompetencer og større viden om sund kost, kategoriserer i analysens institutionsmodeltænkning projektet som et sundhedsprojekt. Opgaveforståelsen betyder, at indsatsen (projektet) har en instrumentel sundhedstilgang til både aktiviteter, deltagere og forældre, der i praksis betyder, at der til at varetage projektet ansættes en fysioterapeut og en diætist uden tilknytning til foreningen til at tilrettelægge det, der i projektdokumentet kaldes "træningsrelaterede aktiviteter" (Michelsen la Cour, 2009, s. 104). De to sundhedsprofessionelle har et tæt samarbejde med forældrene, de fører sundhedssamtaler med forældre og børn, kontrolvejer jævnligt børnene og gennemfører kostaftener i det lokale skolekøkken.

Projektejeren er medlem af Lemvig socialudvalg samtidig med, at han er direktør for Tangsøe Forenede Sportsklubber. Projektorganiseringen foregår på et særligt hold, der kører uden kontakt til andre hold eller foreningen i det hele taget, og projektet forankres ikke i foreningen efter endt projektperiode.

\section{CASE NORDSALLING BOKSEKLUB}

Den anden case, herefter kaldet case Nordsalling Bokseklub, har en opgaveforståelse, der oprindeligt ligger tæt op ad case Tangsøes. Man vil veje børnene efter træning og fokusere på vægtreducerende træningsaktiviteter, men tilgangen opgives af to årsager: Børnene føler sig ubehageligt tilpas ved det, og projektejerne møder modstand mod tilgangen internt $\mathrm{i}$ foreningen. Konflikten omkring tilgangen afsluttes ved, at de oprindelige projektejere trækker sig fra projektet og afløses af andre af foreningens aktive. 
Projektets målgruppe er de 10-13-årige og de 14-17-årige, og det har stor tilslutning. Der har dog ikke været tale om et rekrutteringssamarbejde med sundhedsprofessionelle i lokalområdet. Nordsalling Bokseklub har ikke kunnet skabe et samarbejde med den lokale sundhedsplejerske, da denne ikke har reageret på klubbens henvendelser, og klubbens rekruttering af 63 deltagere er foregået gennem en stor målrettet foreningsindsats og gennem annoncering $\mathrm{i}$ den lokale avis.

Da projektet er forankret i en bokseklub, er aktiviteterne tilrettelagt som boksetræningsaktiviteter, der indebærer krævende fysisk konditionstræning samt bokseteknisk træning. Projektet fastholder 25 deltagere (40 \%) og fortsætter efter endt projektperiode som et permanent hold i foreningen. Forældrene har ikke kunnet inddrages.

\section{CASE IF KVIK}

Den tredje case, herefter kaldet case IF KVIK, er et projekt for de 5-9-årige. Projektet er forankret på den lokale skole, hvis lokaler ligger i forlængelse af den lokale Skolefritidsordning (SFO). Foreningen KVIK dækker tre landsbyer i et område, hvor den lokale skole er lukket. KVIK er efter skolelukningen den eneste organiserede ramme, der tilbyder sociale aktiviteter i lokalsamfundet.

Projektets opgaveforståelse har både et socialt og et fysisk sigte: Gennem fysisk aktivitet skal børnene opnå forbedrede fysiske og sociale kompetencer, der skal føre til et permanent medlemskab af den lokale idrætsforening og forbedrede sociale relationer. Træningen er legepræget og vægter træning af de sociale kompetencer, der er nødvendige for at indgå i legefællesskaber med andre børn. Der arbejdes bevidst med børnenes evne til at samarbejde,

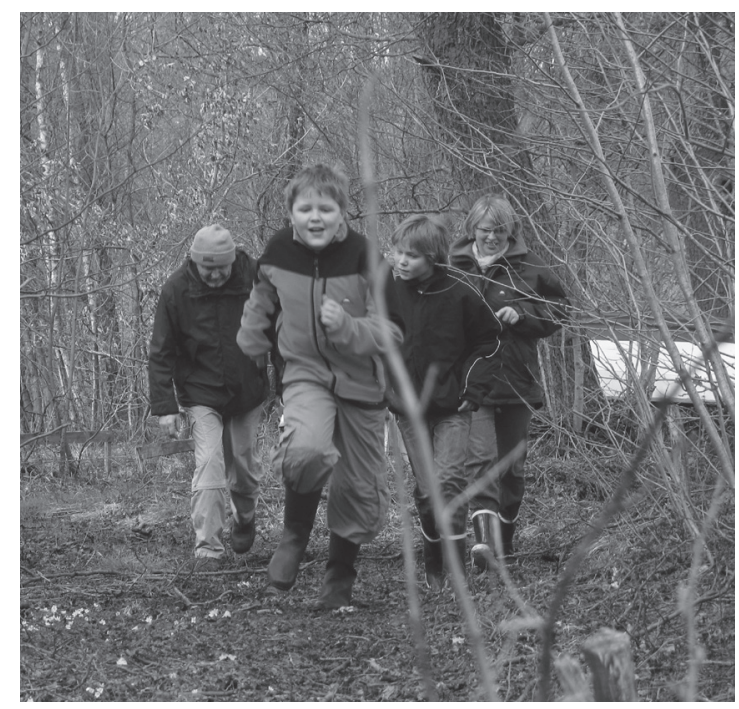

Aktiviteterne i idrætsprojekterne for vanskeligt stillede, overvægtige børn spændte vidt. Her et billede fra et projekt i Viborg. (fotograf: Lone Simonsen)

acceptere regler og andres behov samt fysiske kompetencer i form af motorisk træning, koordination og boldtræning.

Rekruttering er foregået på to måder: Instruktørerne er både idrætslærere på skolen og instruktører i KVIK. Med deres professionelle kendskab til de lokale børn har de kunnet rette henvendelse direkte til dem, der falder inden for projektets målgruppe. Rekrutteringen er derudover foregået $i$ et samarbejde med sundhedsplejersken, der har kunnet formidle kontakten mellem skole, forening og hjem. Der rekrutteres i perioden 20 børn, og de fastholdes alle efterfølgende på et permanent hold. Projektet inddrager forældrene.

Instruktørerne har ikke bare en dobbeltrolle i forhold til lokalsamfundet, den ansvarlige projektejer har kontakt til det lokale byråd i Mariager Fjord Kommune. Projektejeren tager efter 
endt projektperiode initiativ til et nyt projekt for vanskeligt stillede børn og bruger sit kendskab til Mariager Fjord Kommunes socialudvalg til at fortsætte indsatsen.

\section{METODE}

Metodisk bygger evalueringen på et dokumentstudie, der sammen med Kulturministeriets mål for puljen medvirker til at udvikle projektets evalueringsparametre. Studiets dataindsamling er gennemført som kvalitative, semistrukturerede interviews med henholdsvis projektejere og sundhedsprofessionelle, som fokusgruppeinterviews med forældre og pårørende til deltagerne på projekterne og som individuelle samt fokusgruppeinterviews med børnene. Alle interviews er foregået 'on location' i foreningerne i forbindelse med træning eller madaftener. Besøgene involverede deltagerobservation og observerende deltagelse, ligesom deltagelse i madaftener (case Tangsøe) gav mulighed for at gennemføre uformelle samtaler med forældre og børn omkring kvalitative aspekter i projekterne.

I evalueringsfasen indgik flere erfaringsdannelsesseminarer, hvis formål var at afdække, hvori udfordringerne i forhold til at opfylde projektmålene bestod. Projektejernes møde med hinanden førte til en erfaringsudveksling projektejerne imellem. Erfaringsudvekslingsseminarerne medvirkede til at skærpe evalueringskriterierne og skabe de efterfølgende tematiske overvejelser for den sociologiske analyse (Stake, 2005, s. 449).

Afhandlingens sociologiske analyse er bygget op omkring evalueringsstudiets afledte hypoteser. På baggrund af en temabaseret, datadreven case-analyse (Stake, 2005, Neergaard, 2007), bliver det muligt at skabe et komparativt grundlag for analysen af hypoteserne.

Datamaterialet underkastes først en kodning, der fører til en opbygning af matricer, der fortættes og fører til »en anden ordens begrebsliggørelse af data« (van Maanen, 1979) og opbygning af displays. Displayopbygningens analytiske begrebsliggørelse er teoretisk begrundet (Miles og Huberman, 1994, Dahler Larsen, 2002). Herved opnås temaer, der kan bygge bro mellem teoretiske konstruktioner, hypoteser og empiriske iagttagelser (Michelsen la Cour, 2010, s. 94).

\section{KOBLINGEN TIL EN STØRRE SAMFUNDSMASSIG FORSTÅELSE AF INDSATSEN}

Datamaterialet fra evalueringen af dette mulighedsrum fører til tre hypoteser, der i analysen bruges til at undersøge, om idrætsforeninger kan betragtes som socialt ansvarliggjorte, intermediære instanser (Durkheim, 2000, Rasborg, 1998) i et revitaliseret civilsamfund og dermed som et udtryk for det associative demokrati (Kaspersen og Ottesen, 2001). I det associative demokrati gør politiske tiltag i form af f.eks. puljer og forsøgsordninger det muligt at skabe (med)styring gennem civilsamfundsinstitutioner - intermediære instanser. Det antages, at de er tættere på lokale problemer og bedre, billigere og mere effektivt kan skabe relevante løsninger af styringsproblemer (som f.eks. den stigende overvægt eller den stigende marginalisering af vanskeligt stillede grupper (Rasborg, 1998)). De intermediære instanser betragtes af Juul som udtryk for »individers værdier, idealer og mål« (2003, s. 34), der gennem de intermediære instanser bliver til kollektiv bevidsthed gennem opdragelse, uddannelse og moralsk normdannelse (værdier) og dermed til en social integrationsstrategi (Michelsen la Cour, 2010, s. 110).

Det leder til den anden hypotese, at de intermediære instansers integrationsstrategier byg- 
ger på et forbrug af social kapital, der kommer især vanskeligt stillede grupper til gode. Projekterne giver dem en chance for at blive "værdifulde borgere«, når de kommer med noget af værdi til foreningerne (medlemskabet). Den sociale orientering hos projektejerne, der dokumenteres i datamaterialet, kan betragtes som en objektgjort solidaritet (Michelsen la Cour, 2010, s. 187) forankret i en intermediær organisering. Dean (1996) kalder det en refleksiv social orientering mod lokalsamfundet og dets mindre ressourcestærke medlemmer.

Dette teoretiske perspektiv åbner et tredje perspektiv, nemlig den civile adfærd, 'civicness' og 'civility' (Evers, 2009, Dekker, 2009), der som et direkte produkt af synergien mellem en medierende offentlig sfære (Evers, 2009, s. 239), et intermediært offentligt rum (Evers 1995, s. 160) og hele den associative tradition i Danmark (Kaspersen og Thorsager, 2009) bidrager til lo- kalsamfundenes og velfærdsstatens sammenhængskraft.

Til sammen skaber disse teoretiske tilgange en analyseramme for projektejernes metodevalg, der gør det muligt at argumentere for tre institutionelle modeller.

\section{ANALYSE}

De parametre, der anvendes til at skabe tre institutionelle modeller, er fremkommet som en konsekvens af en række forskelle i metoder i forhold til at indfri puljens mål. Forskellene fremkommer ved at sammenligne de særlige metoder, foreningerne har brugt $\mathrm{i}$ forhold til at rekruttere og fastholde de vanskeligt stillede målgrupper, foreningernes forståelse og fremtidsvisioner inden for arbejdet med særlige målgrupper og projektejernes særlige forudsætninger. Der er således ikke alene forskelle i opgaveforståelsen mellem de tre projekter, men der er også væsent-

\begin{tabular}{|c|c|c|c|c|c|c|c|c|c|c|c|c|}
\hline $\begin{array}{l}\ulcorner \\
巳 \\
\frac{\mathscr{U}}{c} \\
\frac{\mathrm{w}}{\mathrm{w}}\end{array}$ & 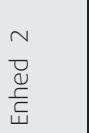 & 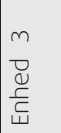 & 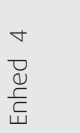 & 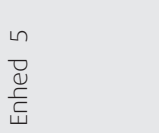 & 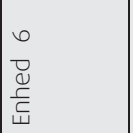 & 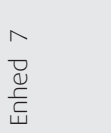 & 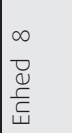 & $\begin{array}{l}a \\
0 \\
\frac{y}{c} \\
\frac{c}{5}\end{array}$ & 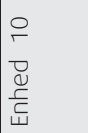 & 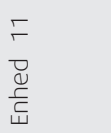 & 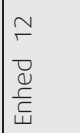 & 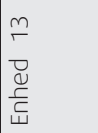 \\
\hline Cases & 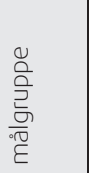 & $\begin{array}{l}0 \\
0 \\
\frac{0}{0} \\
. \frac{0}{6} \\
\frac{0}{>}\end{array}$ & 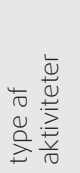 & 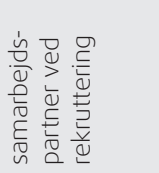 & 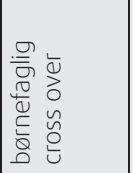 & 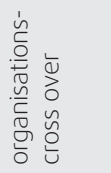 & 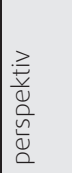 & 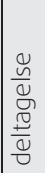 & 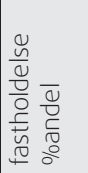 & 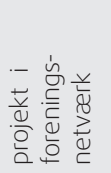 & 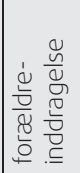 & 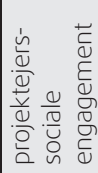 \\
\hline $\begin{array}{l}\text { 1. Tangsøe } \\
\text { Forenede } \\
\text { Sportsklubber } \\
\text { landsby }\end{array}$ & $\begin{array}{l}\text { 5-9år } \\
+10- \\
13 a ̊ r ~\end{array}$ & 3 år & $\begin{array}{l}\text { leg, } \\
\text { sund- } \\
\text { hed, } \\
\text { kost }\end{array}$ & $\begin{array}{l}\text { kommunal } \\
\text { cross over + } \\
\text { annoncering }\end{array}$ & \begin{tabular}{l|} 
ingen \\
børne- \\
faglig \\
cross over
\end{tabular} & $\begin{array}{l}\text { kommu- } \\
\text { nal cross } \\
\text { over }\end{array}$ & kort & 67 & $\begin{array}{l}17 \\
\text { udgør } \\
25 \%\end{array}$ & $\begin{array}{l}\text { udenfor } \\
\text { lønnet } \\
\text { ekstern } \\
\text { udfører }\end{array}$ & ja & stort \\
\hline $\begin{array}{l}\text { 2. Nordsalling } \\
\text { Bokseklub } \\
\text { landsby }\end{array}$ & \begin{tabular}{|l}
$10-$ \\
$13 a ̊ r ~+$ \\
$14-$ \\
$17 a ̊ r ~$
\end{tabular} & 3 år & $\begin{array}{l}\text { vifte, } \\
\text { vand, } \\
\text { sund- } \\
\text { hed }\end{array}$ & $\begin{array}{l}\text { svagt sam- } \\
\text { arbejde, an- } \\
\text { noncering }\end{array}$ & \begin{tabular}{|l|} 
ingen \\
børne- \\
faglig \\
cross over
\end{tabular} & $\begin{array}{l}\text { ingen } \\
\text { kommu- } \\
\text { nal cross } \\
\text { over }\end{array}$ & langt & 63 & $\begin{array}{l}25 \\
\text { udgør } \\
40 \%\end{array}$ & indenfor & nej & stort \\
\hline $\begin{array}{l}\text { 3. IF KVIK } \\
\text { Himmerland } \\
\text { landsby }\end{array}$ & 5-9år & 3 år & vifte & kommunen & $\begin{array}{l}\text { lokal } \\
\text { idrzets- } \\
\text { lдегег }\end{array}$ & $\begin{array}{l}\text { lokal } \\
\text { skole- } \\
\text { cross } \\
\text { over }\end{array}$ & langt & 20 & $\begin{array}{l}20 \\
\text { udgøг } \\
100 \%\end{array}$ & indenfor & ja & stort \\
\hline
\end{tabular}

Figur 1. Matrice - beskrivende datasæet 
lige forskelle $\mathrm{i}$ de anvendte metoder $\mathrm{i}$ forhold til rekruttering, projektindhold og -forløb, opgaveperspektiv, forekomsten af 'cross over' mellem en professionel i en lokal institution og den foreningsfrivillige samt $i$ forhold til metoder i samarbejdet med sundhedsprofessionelle eller andre velfærdsprofessionelle.

Datamaterialets beskrivende datasæt fra de tre cases kodes i forhold til deres betydning for opfyldelse af målene i projekterne. Det drejer sig dels om metoder til rekruttering og fastholdelse, men også om andre fund, der fører til opfyldelse af målene, f.eks. relationer i lokalsamfundet, professionelle kompetencer og socialt engagement. Datamaterialet organiseres dernæst ind i en matrice, der er opbygget som et koordinatsystem med 13 enheder (se fig. 1). Forudsætningen for at fremstille data i en matrice er, at matricen fremstiller hele det beskrivende datasæt (Dahler-Larsen, 2002, s. 32). Projekterne indsættes på den lodrette akse. Datamaterialet, organiseret i enheder, der repræsenter et tema, indsættes på den vandrette akse.

\section{UDDYBNING AF KARAKTERISTIKA FOR REKRUTTERING}

Det er væsentligt for rekrutteringen af især aldersgruppe 1 (5-9 år) og 2 (10-13 år), om foreningen organisatorisk (gennem projektejeren) er forbundet eller kan forbindes med kommunale børneinstitutioner. Om den kan indgå i et samarbejde med professionelle uden for foreningen - sundhedsplejerske, SFO-pædagog eller lærer - og dermed overskride de organisatoriske rammer for børns fritid. Enhederne 5, 6 og 7 rummer data, der bekræfter dette: Projektejerne samarbejder tværorganisatorisk (enhed 5), projektejerne har en børnefaglighed, der forbinder dem med et pædagogisk netværk uden for foreningen (enhed 6), og projektejerne samarbej- der med institutioner i lokalsamfundet (enhed 7). De foreninger, der hverken har samarbejdet på tværs eller været svagt organisatorisk forbundet med børneinstitutioner, har generelt brugt lokalaviserne til at annoncere efter børnene. De foreninger, der ved at etablere et samarbejde med kommunen omkring rekruttering har fået fat i målgruppen, udviser associative træk, der kan bruges til at implementere indsatser. De medvirker dermed til at skabe velfærd.

Rekruttering lykkes i de tilfælde, hvor foreningerne

- har samarbejdet inden for eller ud over foreningens rammer

- har organisatoriske kompetencer

- har et langt projektperspektiv

- har en projektejer med en professionel forankring i en organisation

- har et perspektiv på indsatsen, der overskrider foreningsperspektivet

- har en projektejer, der inddrager et børnevelfærdsperspektiv

\section{UDDYBNING AF KARAKTERISTIKA FOR FASTHOLDELSE}

Det er væsentligt for fastholdelsen af især aldersgruppe 1 og 2, at aktiviteterne er tilpasset målgruppen (enhed 4), om projektejeren har en børnefaglig baggrund, der gør ham/hende i stand til at udvikle børnenes sociale kompetencer (enhed 6), og om børnene gennem projektejeren forbindes med foreningens netværk (enhed 11) (se fig. 2 på næste side). Det er også væsentligt, at målgruppen har fået tilbudt særlige hold med særlige aktiviteter (enhed 5). De foreninger, der har ansat en udefrakommende instruktør, har ikke fået forbundet børnene med foreningens netværk. Væsentligt er derfor, om projektejeren er rekrutteret fra foreningens 
eget netværk, ligesom det er væsentligt, om projektejerens engagement kan »bære« de udfordringer, der er forbundet med den særlige målgruppe - samspillet mellem social udsathed og manglende kompetencer, fysiske som sociale. Her er pædagogiske kompetencer væsentlige i forhold til at indfri målene i puljen.

Fastholdelse lykkes i de tilfælde, hvor foreningen

- har lavet aktiviteter baseret på leg, ikke træning

- har haft pædagogiske kompetencer

- har lavet særligt tilpassede aktiviteter på særlige hold
- har haft et langt tidsperspektiv

- hvor projektejeren er en del af foreningens netværk

Displayet nedenfor repræsenterer en fortætning af de beskrivende data og interviewdata $\mathrm{i}$ forhold til de tre teoretiske perspektiver (figur 2). I displayet sammenholdes de beskrivende data med data fra interviews og fokusgruppeinterviews og organiseres i enheder med nedenstående datainformation, og der finder en analytisk fortætning af data sted, fremstillet i et display med otte enheder. De otte enheder præsenteres her:

\begin{tabular}{|c|c|c|c|c|c|c|c|c|}
\hline & Enhed 1 & Enhed 2 & Enhed 3 & Enhed 4 & Enhed 5 & Enhed 6 & Enhed 7 & Enhed 8 \\
\hline $\begin{array}{l}\text { karakte- } \\
\text { ristika og } \\
\text { model-træk }\end{array}$ & $\begin{array}{l}\text { projekt- } \\
\text { perspektiv }\end{array}$ & $\begin{array}{l}\text { samarbejds- } \\
\text { relationer } \\
\text { ved rekrut- } \\
\text { tering }\end{array}$ & $\begin{array}{l}\text { organisa- } \\
\text { tions- } \\
\text { cross over }\end{array}$ & $\begin{array}{l}\text { institutionel } \\
\text { effekt }\end{array}$ & \begin{tabular}{|l|} 
professionelt \\
forenings- \\
børnefamilie- \\
netværk
\end{tabular} & \begin{tabular}{|l|} 
børne- \\
professionel \\
kompetence
\end{tabular} & \begin{tabular}{|l|} 
aktør- \\
karakteristika
\end{tabular} & syntese \\
\hline $\begin{array}{l}\text { 1. Tangsøe } \\
\text { Forenede } \\
\text { Sportsklub- } \\
\text { ber } \\
\text { Den sund- } \\
\text { heds- } \\
\text { institutionel- } \\
\text { le model }\end{array}$ & $\begin{array}{l}\text { langt } \\
\text { ekstraor- } \\
\text { ganisatorisk } \\
\text { perspektiv }\end{array}$ & $\begin{array}{l}\text { professionel } \\
\text { opgave- } \\
\text { løsning }\end{array}$ & cross over & $\begin{array}{l}\text { forandrings- } \\
\text { potentiale }\end{array}$ & $\begin{array}{l}\text { ingen cross } \\
\text { over }\end{array}$ & $\begin{array}{l}\text { ingen børne- } \\
\text { professionel } \\
\text { kompetence }\end{array}$ & $\begin{array}{l}\text { ansat udefra } \\
\text { refleksiv } \\
\text { solidaritet }\end{array}$ & \begin{tabular}{|l} 
lille \\
»skæbne«- \\
netværk \\
velfærd gn. \\
individuel \\
sundhed
\end{tabular} \\
\hline $\begin{array}{l}\text { 2. Nordsal- } \\
\text { ling Bokse- } \\
\text { klub } \\
\text { Den } \\
\text { civilsam- } \\
\text { fundsinsti- } \\
\text { tutionelle } \\
\text { model }\end{array}$ & $\begin{array}{l}\text { langt tvær- } \\
\text { organisato- } \\
\text { risk } \\
\text { perspektiv }\end{array}$ & $\begin{array}{l}\text { horisontale } \\
\text { samarbejds- } \\
\text { relationer } \\
\text { grundet svag } \\
\text { kommunal } \\
\text { støtte }\end{array}$ & $\begin{array}{l}\text { ingen cross } \\
\text { over }\end{array}$ & $\begin{array}{l}\text { forandrings- } \\
\text { potentiale }\end{array}$ & \begin{tabular}{|l|} 
mangler \\
forenings- \\
børnefamilie- \\
netværk
\end{tabular} & \begin{tabular}{|l|} 
ingen \\
børne- \\
professionel \\
kompetence
\end{tabular} & $\begin{array}{l}\text { forenings- } \\
\text { ildsjæel } \\
\text { refleksiv } \\
\text { solidaritet }\end{array}$ & $\begin{array}{l}\text { stærkt } \\
\text { netvæerk = } \\
\text { forenings- } \\
\text { fællesskab }\end{array}$ \\
\hline $\begin{array}{l}\text { 3. IF Kvik } \\
\text { Den vel- } \\
\text { færds- } \\
\text { institutio- } \\
\text { nelle } \\
\text { model }\end{array}$ & $\begin{array}{l}\text { langt } \\
\text { tvæerorga- } \\
\text { nisatorisk } \\
\text { perspektiv }\end{array}$ & $\begin{array}{l}\text { vertikale } \\
\text { tværorgani- } \\
\text { satoriske } \\
\text { relationer }\end{array}$ & cross over & $\begin{array}{l}\text { forandrings- } \\
\text { potentiale }\end{array}$ & \begin{tabular}{|l|} 
professionelt \\
forenings- \\
børnefamilie- \\
netværk
\end{tabular} & $\begin{array}{l}\text { børne- } \\
\text { professionel } \\
\text { kompetence }\end{array}$ & \begin{tabular}{|l} 
social \\
entreprenør \\
refleksiv \\
solidaritet
\end{tabular} & $\begin{array}{l}\text { høj grad } \\
\text { af profes- } \\
\text { sionalisme + } \\
\text { svagt } \\
\text { netværk = } \\
\text { velfærd gn. } \\
\text { fæellesskab }\end{array}$ \\
\hline
\end{tabular}

Figur 2. Display 


\section{KONKLUSION}

De tre teoretiske perspektiver giver sammen med datamaterialet anledning til at udarbejde tre institutionelle modeller. Modellerne bygger på de organisatoriske træk, projektets metoder viser, at de enkelte foreninger har. Ligeledes er modellerne bygget op over sammenfald i og afvigelser mellem karakteristika i forhold til de valgte teoriperspektiver. Syntesen mellem hypoteser, teori og empiri danner grundlag for at skabe følgende tre institutionelle modeller:

\section{Den velfærdsinstitutionelle model}

2. Den civilsamfundsinstitutionelle model

3. Den sundhedsinstitutionelle model

I forhold til rekruttering er det i et velfærdspolitisk perspektiv interessant at skelne mellem tre forskellige modeller. Det er det, når den velfoerdsinstitutionelle model mobiliserer tværgående netværker med kommunale organisationer, og børnene får adgang til og bliver en del af foreningens og civilsamfundets netværk. Indsatsen har professionelle træk.

Det er også velfærdspolitisk interessant, når den civilsamfundsinstitutionelle model mobiliserer netværket internt $\mathrm{i}$ foreningen for at rekruttere børnene, fordi børnene bliver en del af foreningens netværk, og netværker kan virke som værn mod sociale problemer. Indsatsen kan have professionelle træk.

Det er også velfærdspolitisk interessant at sammenligne med konsekvensen af, at den sundhedsinstitutionelle model samarbejder med en lønnet medarbejder, der er rekrutteret uden for foreningens netværk. Indsatsen er ikke netværksbunden, og børnene kommer derfor ikke ind $\mathrm{i}$ foreningens netværk. Indsatsen er professionel og fastholder børnene i en identitet som overvægtige, ikke som idrætsudøvere. Men ind- satsen fører alligevel til fastholdelse og kan skabe øget sundhed for den enkelte familie.

I forhold til fastholdelse er det i et velfærdspolitisk perspektiv interessant at skelne mellem tre forskellige modeller. Det er det, fordi der inden for rammerne af den velfaerdsinstitutionelle model skabes velfærd, når foreningen er i stand til at skabe adgang for overvægtige børn. Dermed skabes der adgang for vanskeligt stillede familier og deres børn, og foreningerne er velegnede til at indgå i statslige styringsbestræbelser. Disse foreninger skaber netværker på åbne civilsamfundsbetingelser - solidaritet og tillid og de repræsenterer det ansvarliggjorte civilsamfund. Foreningerne er åbne og netværksskabende og samarbejder vertikalt med statslige institutioner. Den sociale kapital, der gør indsatsens velfærdsmagere til succesfulde skabere af social kapital, forbruges gennem synergi mellem staten og foreningerne/projektejeren, og aktørernes relationer kan betegnes som indlejrede $\mathrm{i}$ hinanden eksemplificeret i det, jeg har kaldt 'cross over': De er både forankret i civilsamfundets institutioner og i lokalområdets offentlige institutioner. Der ligger et stort velfærdsstyringspotentiale i den velfærdsinstitutionelle model. Aktørens refleksive solidariske perspektiv overskrider det afgrænsede foreningsfællesskab, det er præget af et engagement $i$ forhold til børns trivsel generelt, og aktøren har kompetencer til at skabe tillid i målgruppen. Børnene ses som medlemmer.

Inden for rammerne af den civilsamfundsinstitutionelle model skabes også velfærd, men først og fremmest velfærd inden for fællesskaber og ikke mindst for det afgrænsede og specifikke fællesskabs skyld. Foreningernes korporative (lukkede) træk er fremtrædende, deres samarbejdsrelationer er udpræget intra-organisatoriske og horisontale. Aktørernes solidariske per- 
spektiv er indskrænket af foreningsperspektivet, hvilket ikke er en kvalitativ forringelse, men en begrænsning i forhold til målgruppen. Aktørerne i den civilsamfundsinstitutionelle model udfører en velfærdsstatslig opgave ved at skabe og styrke børnefællesskaber, men indsatsen udføres i horisontale netværker, og det forbliver ubekræftet, om det styringsmæssige potentiale er stort nok til at gøre foreningsmagerne til stabile velfærdspartnere. Børnene ses som medlemmer.

Inden for rammerne af den sundhedsinstitutionelle model udføres også en velfærdsstatslig styringsopgave, og også her skabes velfærd for den enkelte familie. Her er fællesskabet ikke målet. De to sundhedsprojekter inddrager ikke civilsamfundets netværker, og effekten er ikke at skabe solidaritet og tillid. Sundhedsprojekterne bruger leg og fysisk træning, ligesom en del af de andre projekter, og har et væsentligt individuelt sundhedsfokus, der i det ene projekt udmøntes i individuelle handleplaner, kostplaner, kontrolvejning af børnene, sundhedssamtaler med forældrene og kostvejledning. Fokus er på den individuelle sundhed, på forældreinddragelse og på forebyggelse gennem information. Børnene ses som klienter.

Projekternes mål var at skabe adgang til og permanent medlemskab af idrætsforeninger for vanskeligt stillede, overvægtige børn og unge. Det er, som analysen viser, på forskellige baggrunde lykkedes, men lige så vigtigt er det, at projekterne skaber en politisk understøttelse af den solidariske adfærd i civilsamfundets institutioner og inddragelse af den enkelte borgers forholden sig til civile dyder som medansvar, solidarisk adfærd og social integration.

Den sociologiske analyse af de forskellige metoder, foreningernes projektejere anvender i op- gaveløsningen, viser, at metoderne adskiller sig ikke bare $\mathrm{i}$ forhold til rekruttering og fastholdelse af målgruppen, men også i forhold til samarbejdet med velfærdsprofessionelle. Velfærdspolitisk kan modellerne bruges til at målrette et fremtidigt samarbejde mellem velfærdsstaten og den frivillige foreningsorganisering.

\section{LITTERATURLISTE}

Dahler-Larsen, P. (2002). At fremstille kvalitative data. Odense: Odense Universitetsforlag.

Dean, J. (1996). Solidarity of Strangers. University of California Press.

Dekker, Paul (2009). „Civicness: From Civil Society to Civic Services«. Voluntas 20(2), 220-239.

Durkheim, E. (2000[1902/1930]). Om den sociale arbejdsdeling. København: Hans Reitzels Forlag.

Evers, A. (1995). "Part of the Welfare Mix: the third sector as an intermediate area«. Voluntas 6(2), s. 159-182.

Evers, A. (2009). "Civicness and Civility: Their Meanings for Social Services«. Voluntas 20(2), s. 239-259.

Hegland, T. J. (2001). Samfundsmassige andringsstrategier via lokale forsøg/eksperimenter. Aalborg: Aalborg Universitetsforlag.

Hirst, P. (1994). Associative Democracy. Cambridge: Polity Press.

Ibsen, B. (2006b). Foreningslivet i Danmark. SFI 6, s.18. 
Ibsen, B. \& Eichberg, H. (2006). Dansk idraetspolitik - mellem frivillighed og statslig styring. København: Idrættens Analyseinstitut.

Juul, S. (2003). Modernitet, velfaerd og solidaritet. En undersøgelse af danskernes moralske forpligtelser. København: Hans Reitzels Forlag.

Kaspersen L. B. \& Ottesen, L. ( 2001). "Associationalism for 150 Years and Still Alive and Kicking: Some Reflections on Danish Civil Society «. I: P. Hirst \& V. Bader (red.) Associative Democracy: The Real Third Way. London: Frank Cass, s.105-130.

Kaspersen L. B. \& Thorsager L. (2009). „Det associative demokrati«. I: Klassisk og moderne politisk teori. København: Hans Reitzels Forlag.

Michelsen la Cour, A. (2009) Virker det? Og I givet fald hvorfor? Evalueringsrapport, Københavns Universitet Institut for Idræt.

Michelsen la Cour, A. (2010). Idroetsforeningers velfaerdspotentiale. En sociologisk analyse af sammenhoengen mellem velfardspolitik, social kapital og socialt entreprenørskab i 21 idrcetsprojekter for vanskeligt stillede børn. Ph.d.-afhandling, Københavns Universitet, Institut for Idræt.
Miles, M. B. \& Huberman, A. M. (1994). Qualitative Data Analysis. 2.udg. London: SAGE.

Neergaard, H. (2007). Udvaelgelse af cases $i$ kvalitative undersøgelser. Samfundslitteratur.

Pilgaard, M. (2008). Danskernes motions- og sportsvaner 2007. København: Idrættens analyseinstitut.

Rasborg, K. (1998). „Velfærdsstaten og det revitaliserede samfund «. I: A. Greve (red.) Sociologien om velfaerd - gensyn med Emile Durkheim. Roskilde: Roskilde Universitetsforlag.

Stake, R. (2005). „Qualitative Case Studies«. I: N. K. Denzin \& Y. S. Lincoln (red.) The Handbook of Qualitative Research. London: SAGE.

van Maanen, J. W. (1979). "The Fact of Fiction in Organizational Ethnography«. Administrative Science Quarterly, 24, s. 539-611.

\section{NOTER}

1. Kulturministeriets pulje "Idrætsprojekter for vanskeligt stillede børn og unge«, 2006.

2. $83 \%$ af alle $7-15$-årige dyrker ifølge en undersøgelse organiseret eller selvorganiseret idræt (Pilgaard, 2008). 